\title{
Akademisyenlerde Örgütsel Öğrenme ve Örgütsel Vatandaşlık Davranışının İş Tatmini Üzerindeki Etkileri ${ }^{1}$
}

\author{
Ebru TEKINN² ${ }^{2}$ Şükran SIRKINTIOĞLU YILDIRIM ${ }^{3 *}$
}

Geliş Tarihi/Received: 19.10 .2020

Kabul Tarihi/Accepted: 28.10.2020

Araştırma Makalesi/Research Article

\section{ÖZET}

Günümüzde işletmeler varlıklarını sürdürebilmek için öğrenmeye ihtiyaç duymaktadırlar. Örgütsel öğrenmenin varlığı öğrenilen bilgilerin o işle ilgili olmasına ve uygulanabilir olmasına bağlıdır. Ayrıca işletmelerin varlıklarını devam ettirebilmeleri açısından önemli bir diğer kavram örgütsel vatandaşlık davranışıdır. Bireylerin çalışma ortamında bildiklerini paylaşması, birbirlerine yardımcı olmaları iş tatmini açısından önem arz etmektedir. Çalışmanın amacı, örgütsel öğrenme ve örgütsel vatandaşlık davranışının iş tatmini üzerindeki etkisini incelemektir. Bu amaç çerçevesinde 256 akademisyene anket çalışması uygulanmıştır. Elde edilen veriler regresyon analizi ile test edilmiştir. Yapılan analizler sonucunda örgütsel öğrenme ve örgütsel vatandaşlık davranışının alt boyutlarının iş tatmini üzerinde etkili olduğu görülmüştür. Bu kapsamda örgütsel öğrenmenin deneyim boyutunun iş tatmini üzerinde pozitif yönde anlamlı bir etkisi olduğu görülmüştür. Ayrıca örgütsel vatandaşlık davranışının centilmenlik ve sivil erdem boyutlarının iş tatmini üzerinde pozitif yönde anlamlı etkisi tespit edilmiştir.

Anahtar kelimeler: Öğrenme, Örgütsel Öğrenme, Örgütsel Vatandaşlık Davranış1, İş Tatmini.

\footnotetext{
${ }^{1} \mathrm{Bu}$ çalışma, Dr. Öğr. Üyesi Şükran SIRKINTIOĞLU YILDIRIM danışmanlığında Kastamonu Üniversitesi Sosyal Bilimler Enstitüsü’nde yürütülen “Örgütsel Öğrenme ve Örgütsel Vatandaşlık Davranışının İş Tatmini Üzerindeki Etkileri" başlıklı yüksek lisans tezinden üretilmiştir.

${ }^{2}$ Bilim Uzman1, Orcid No: 0000-0002-7282-4477

${ }^{3}$ Dr. Öğr. Üyesi, Kastamonu Üniversitesi, İktisadi ve İdari Bilimler Fakültesi, Finans ve Bankacılık Bölümü, Orcid No: 0000-0002-3578-4074

* Sorumlu yazar/Corresponding author

E-mail/e-ileti: ssirkintioglu@ kastamonu.edu.tr 


\title{
The Effect of Organizational Learning and Organizational Citizenship Behavior on Job Satisfaction
}

\begin{abstract}
Today, businesses need to learn in order to survive. The existence of organizational learning depends on whether the information learned is relevant and applicable to the job. In addition, another important concept for businesses to survive is organizational citizenship behavior. It is important for individuals to share what they know in the work environment and to help each other in terms of job satisfaction. The main purpose of the study is to examine the effect of organizational learning and organizational citizenship behavior on job satisfaction. For this purpose, a questionnaire was applied to 256 academicians. The data obtained were tested by regression analysis. As a result of the analysis, it was seen that the sub-dimensions of organizational learning and organizational citizenship behavior were effective on job satisfaction. In this context, it has been observed that the experience dimension of organizational learning has a significant positive effect on job satisfaction. In addition, a significant positive effect of the dimensions of gentleman's and civic virtue of organizational citizenship behavior on job satisfaction was determined.
\end{abstract}

Keywords: Learning, Organizational Learning, Organizational Citizenship Behavior, Job Satisfaction.

\section{GİRIŞ}

Günümüzde Farklı yönlerden incelenebilen öğrenme kavramı, canlı varlıkları diğer varlıklardan ayırmada etken olmakla birlikte özellikle insanlar için varlıklarını devam ettirebilmeleri adına oldukça önemli bir özelliktir. İnsanlar, öğrenme sayesinde hiçbir bilgileri yokken yaşamını sürdürecek bilgi ve tecrübeyi elde ederek varlığını idame ettirmeye çalışır (Demirel ve Tohum, 2018). Tüm sektörlerde, rekabette öncü olabilmenin yolu yeniliklere ayak uydurmak, değişen teknolojiyi örgüte adapte etmek ve en önemlisi çalışanlarını yeni gelişimlere yanıt verebilecek derecede geliştirmektir. Bu da örgütsel öğrenmeyle mümkün olmaktadır. Örgütsel öğrenme sayesinde örgütler gelişmekte ve çalışanlar birbirlerinden öğrendikleri sayesinde daha etkili hale gelmektedir. Örgütlerin başarılı olabilmelerinde önemli olan bir diğer nokta, işinden ve iş yaşamının kalitesinden tatmin olan çalışanlar da büyük önem taşımaktadır. Çalışanların işe yönelik tatmin düzeylerinin yüksek olması durumunda performansları ve verimlilikleri de artacaktır (Özer, 2013). 
Örgütler açısından önemli olan bir diğer kavram, örgütsel vatandaşlık davranışı olarak bilinen biçimsel rol davranışlarının dışında gönüllülük esasına dayalı olarak gerçekleştirilen davranışlardır. Örneğin, hırsızlık gibi olumsuz durumlarda diğerine haber verme, aşırı iş yükü ile uğraşan çalışana yardım etme gibi davranışlar çalışanın örgütü sahiplenmesi açısından önemlidir ve örgütte huzurlu bir iş ortamı yaratır. İşine karşı olumlu duygular besleyen bireyin, tatmin düzeyi yüksek olacaktır. İşinden tatmin olan bireyde, örgütsel vatandaşlık davranışının da yüksek olduğu görülmektedir (Kaymakçı, 2013).

Buradan hareketle yapılan çalışma Ankara Üniversitesi, Gazi Üniversitesi ve Kastamonu Üniversitesinde bulunan akademisyenlerin örgütsel öğrenme ve örgütsel vatandaşlık davranışlarının iş tatmini üzerindeki etkisini görmek amacıyla hazırlanmıştır. $\mathrm{Bu}$ amaç çerçevesinde giriş bölümünü takiben araştırmanın kavramsal çerçevesine yer verilmiştir. Daha sonra araştırmanın kapsamını ve örneklemini, kullanılan ölçekleri, ölçüm yöntemlerini ve verilerin analizlerini içeren araştırma metodolojisine yer verilmiştir. En son verilerin analizinden yola çıkarak ulaşılan bulgular 1şı̆̆ında sonuç bölümü sunularak çalışma sonlandırılmıştır.

\section{LITERATÜR TARAMASI}

\section{1. Örgütsel Öğrenme}

Örgütler, açık sistem ve canlı birer organizma şeklinde ele alınmaktadırlar. Örgütler de bütün canlı organizmalar gibi mevcudiyetlerini devam ettirmek, bütün paydaşlarına kalifiye hizmetlerde bulunmak ve entropiyle başa çıkabilmek için çevrelerinde oluşan değişimlere adapte olmak, kendilerini yetkinleştirmek ve devamlı olarak öğrenmek zorundadırlar. Modern anlayışta, bireyler gibi örgütlerin de öğrenmeleri, topladıkları bilgileri örgütle paylaşmaları ve aktarmaları, ihtiyaç olduğunda tekrar kullanmaları düşünülmektedir (Alanoğlu, 2014). Öğrenme, "istenilen duruma gelinebilmesi için ömür boyu devam eden bir bilgi edinme süreci” şeklinde açıklanmaktadır. Öğrenilenlerin işle ilgili olması, uygulanmaya elverişli olması ve bir geri dönüşümünün olması durumunda öğrenme, örgütsel öğrenme olarak tanımlanmaktadır (Barutçugil, 2004).

İlk olarak Cyert ve March (1963) tarafından ortaya atılan örgütsel öğrenme terimi, örgütün problem giderme ve iş gerçekleştirme kapasitesinin kuvvetlendirilmesi ve örgütün çevreye adapte olma süreci şeklinde açıklanmıştır (Öncül, 1999). Örgütsel öğrenme, iş dünyasında 1970”li yıllarda ele alınmış ve Argyris tarafından, yanlışların tespit edilmesi ve doğrulanması süreci biçiminde tanımlanmıştır. Çalışanların gelişmelerinin sağlanabilmesi ve 
örgüt çıkarlarının uygulanabilmesi bakımından öğrenmenin önemi gittikçe artmaktadır. Ancak bireysel öğrenme olmadan örgütsel öğrenme tam anlamıyla gerçekleşmemektedir. Bu yüzden çalışanlar, ekip ruhuyla hareket etmeli ve işbirliği içerisinde öğrenme sonuçlarını birbirleriyle paylaşmalıdır. Bunu gerçekleştirmenin yolu, örgüt içi iletişimi canlı tutmaktır (Aksoytürk, 2008). Öğrenmenin organizasyona kattı̆̆ı değer bununla da kalmamaktadır. Sonuçta işletmeler oluşturdukları mal ve hizmetlerle, odaklandı ğı kitleler ve hâkim oldukları pazarlarla önemli duruma gelmektedir. Tüm bunları başarmanın yolu ise çevreyle uyumlu olmak ve çevreye duyarlı olmaktan geçer. Çevredeki değişim ise hızlı bir öğrenmeyi zorunlu kılmaktadır. Örgütsel öğrenmenin beş tane alt boyutu bulunmaktadır. Bunlar: deneyim, risk alma, dış çevre ile etkileşim, iletişim ve katılımcı karar vermedir.

Deneyim: Organizasyonun önerilere ve yeni düşüncelere ne dereceye kadar açık olduğu manasına gelen deneyim, farklı yöntemlerin olası kullanımına dayanan, sorunlara yenilikçi çözüm arayışını içermektedir (Nevis, Dibella, ve Gould, 1995). Deneyim, örgütsel öğrenme literatüründe en çok kabul gören boyut olup genel itibariyle, örgütte çalışanlar tarafından yeni fikirleri deneme isteği olarak tanımlanmaktadır. İşlerin nasıl yürüdüğünü merak etme, işs süreçlerinde değişiklik yapma gibi anlamları da mevcuttur (Chiva ve Alegre, 2008).

Risk Alma: Risk alma, belirsizlik, belirsiz durumlara ve hatalara karşı tolerans anlamlarına gelmektedir (Chiva ve Alegre, 2008). Her ne kadar sifir hata, maliyetleri minimuma indirme gibi kavramlar karşımıza çıksa da örgütsel öğrenme için hatalar oldukça önemlidir. Şöyle ki, ampulün icadında, Edison yaptığı birçok çalışmanın sonucunda başarısız olsa da, o iş sonucunu etkilemeyen birçok işlem biliyorum demiştir. Dolayısıyla, örgütler hatalardan korkup risk almasalar da yaptıkları hatalar sonucunda birçok şey öğrenebilmektedirler (Horuz, 2018).

Dış Çevre ile Etkileşim: Dış çevre ile etkileşim bir işletmenin bulunduğu ortam ve çevresi ile sürdürdüğü ilişkilerin kapsamı olarak ifade edilmektedir. Çevre ile olan etkileşim öğrenmede oldukça önemlidir ve örgütsel öğrenme üzerinde de etkisi büyüktür. Örgütün çevresi ile bağlantısı önemlidir çünkü örgüt değişen çevre koşullarıyla aynı anda gelişmek zorundadır ve örgüt değişen çevresiyle eşzamanlı olarak değişmeye ve kendine katma değer sağlamaya çalışmaktadır (Chiva ve Alegre, 2008).

İletişim: Örgütsel öğrenme açısından hayati önem taşıyan diyaloğu, genel itibariyle günlük tecrübeyi oluşturan süreçler, öngörüler ve kesinlikler içinde tüm paydaşlarla etkileşim kurmayı sağlayan sürekli ve kolektif bir sorgulama olarak ifade edebiliriz. 
Katılımcı Karar Verme: Katılımcı karar verme, çalışanların karar verme sürecindeki etki derecesini ifade etmektedir. Örgütler, iş tatmini, çalışan katılımı ve örgütsel bağlılığın motive edici etkilerinden yararlanabilmek için katılımcı karar alırlar (Chiva ve Alegre, 2008). Literatür, öğrenmeyi kolaylaştıran yönlerden biri olarak katılımcı karar vermeyi görmektedir. Örgütlerin katılımcı karar verme süreçlerine etkili bir şekilde katılım sağlayabilmeleri için çalışanların duygusal zekâlarını arttırmaları gerekmektedir. Buna ek olarak, katılımcı karar vermenin bilgiye ulaşmada kolaylık sağladığı ve verilen kararın kalitesini arttırdığı savunulmaktadır (Scott ve Christopher, 2004).

\section{2. Örgütsel Vatandaşıık Davranışı}

İnsanların yerleşik hayata geçip, yaşamlarını siyasal bir gücün altında sürdürmesiyle birlikte, vatandaşlık kavramı türemiştir. Toplu biçimde yaşayan insanların üretimde gösterdikleri çabalar sonucunda sanayi gelişmiş, endüstriyel toplumlar meydana gelmiş ve nihayetinde endüstriyel vatandaşlık kavramı ortaya çıkmıştır. Günümüze gelindiğinde ise pazar, pazarlama ve rekabet ifadelerinin iş yaşamının gerekli parçaları olmalarıyla, bir topluluğa aitlikten ziyade bireylerin tüm becerilerinin ve etkinliklerinin iş maksatlı olarak daha kârlı tüketilmesi maksadıyla örgütsel vatandaşlık oluşmuştur (Atalay, 2005). Örgütsel vatandaşlık davranışı normal rol beklentilerinin ötesinde, resmi ödül sistemi ile ilgili olmayan isteğe bağlı iş davranışlarıdır (Bateman ve Organ, 1983). Örgütsel vatandaşlık davranışının diğergamlık, vicdanlılık, nezaket, centilmenlik ve sivil erdem olmak üzere beş temel boyutu mevcuttur.

Diğgergamlık: Örgütteki çalışanların meydana gelen sorunlar karşısında gönüllü ve bilinçli bir şekilde, diğer çalışanlara yardımcı olunması şeklinde ifade edilmektedir (Aquino ve Bommer, 2003). Lambert'in (2010) deyimiyle diğergamlık, çalışanların gönüllü olarak iş yaptıklarını ve diğer çalışma arkadaşlarına sorulmadan onların işlerine de yardım etmelerini ifade etmektedir. Lepine ve diğerlerine (2002) göre, işe gelmeyen iş arkadaşlarının işini yapma, mecburi olmayan görevlerde istekli davranma, örgüte gelen yeni çalışanları örgüte alıştırma, işi fazla olan arkadaşlara yardımcı olma diğergamlığa örnek olarak gösterilen davranışlardır.

Vicdanlılık: Vicdan, iş ahlakının gereklilikleri dışında isteğe bağlı ekstra rol davranışları olarak ifade edilmektedir (Joo ve Soonkwan, 2008). Mackenzie ve diğerlerine (1993) göre vicdanlılık, kurumun biçimsel rollerinin çok ötesinde isteğe bağlı davranışları kapsamaktadır. Çetin'in (2004) deyimiyle çalışanın olumsuz durumlarda bile işe vaktinde gelmeye çaba harcaması vicdanlılıktır. Dolayısıyla olması gerekenden daha fazlasını yapmayı 


\section{Tekin, E., Sırkıntıoğlu Yıldırım, Ş.}

gerektirir. Sezgin (2005) ve Gürbüz’e (2006) göre vicdanlılığa örnek olarak gösterilebilecek davranışlar, mesai ücreti verilmediği halde işi bitirmeye çalışma, örgütte belirlenen kurallara uyma, molaları dikkatli kullanma şeklinde ifade edilmektedir.

Nezaket: Çalışanın, örgüt içerisinde beraber çalıştığı arkadaşlarını oluşabilecek sorunlara karşı uyarması, haberdar etmesi gibi davranışlardır (Deluga, 1995). Lo ve Ramayah'a (2009) göre nezaket, bir çalışanın diğer çalışanların hevesi kırıldığında ve motivasyonu düştüğünde o çalışanları cesaretlendirmesi olarak ifade edilmektedir. Örgütte karar alınırken çalışanların fikrinin alınması, alınan kararların diğer çalışanlarla paylaşılması, ileri tarihteki su kesintisinin çalışanlara önceden haber verilmesi nezaket boyutuyla ilgilidir (Podsakoff, Mackenzie, Paine ve Bachrach, 2000).

Centilmenlik: Centilmenlik, çalışanın stresten uzak, hoşgörülü olması şeklinde ifade edilmektedir (Organ, 1988). Curry’e (2016) göre centilmenlik, işler ters gittiği zaman bile pozitif davranan çalışanı ve çalışma ekibi için şahsi çıkarlarını feda etmeye gönüllü olmasını vurgulamaktadır. Bu boyut için problemleri lüzumsuz yere büyütmeyen, zamanının çoğunu işiyle geçiren, çalışma arkadaşlarına kaba davranmaktan korkan kişinin bu ve benzeri davranışları örnek gösterilebilir (Kayan, 2011). Sonuç olarak, bir örgütte centilmenlik davranışlarının yokluğu, örgütte mutluluğun ve örgütsel bağlılığın azalmasına neden olmaktadır (Basım ve Şeşen, 2006).

Sivil Erdem: Schnake ve Dumler'e (1993) göre sivil erdem, örgütü ilgilendiren olaylar karşısında örgüt çalışanlarının sorumluluk alarak, alınacak kararlara ve toplantılara istekli bir şekilde katılımları şeklinde açıklanmaktadır. Örgüt çevresinde meydana gelen değişime karşı hassas olma, bilgi toplama ve toplanan bilgiyi çalışma arkadaşları ile paylaşma konusunda istekli olma gibi davranışlar, sivil erdem altında incelenmektedir (Allison, 2001).

\section{3. İş Tatmini}

İş tatmini kavramı, sanayi devriminden hemen sonra üretime geçilen endüstri dalında örgütsel psikoloji ve eğitim dallarında incelenmeye başlanmıştır (Toplu, 1998). İş tatmini kavramı, klasik dönemde çok fazla dikkate alınmayan, modern ve modern sonrası yönetim yaklaşımları ile birlikte konuşulmaya başlanan bir kavram iken günümüzde çalışma ortamlarında önemli kavramlardan biri haline gelmiştir (Tekin, 2019). Birçok yazar tarafından çeşitli şekillerde dile getirilen iş tatmini ya da tatminsizliği, yalnızca iş hayatını değil kişinin özel hayatını da etkileyebilmektedir. Şöyle ki günlük hayatlarının önemli bir bölümünü çalışarak geçiren bireyler, iş hayatında yaşadıkları duygu ve düşünceleri özel hayatlarına da 
yansıtabilmektedirler. Dolayısıyla, iş tatmini, bireylerin iş yerindeki mutluluklarıyla birlikte özel hayatlarındaki mutluluklarını da olumlu şekilde etkileyebilmektedir. Çalışanların işlerinde sergiledikleri olumlu davranışlar iş tatmini; olumsuz davranışlar ise iş tatminsizliği olarak nitelendirilir (Vroom, 1967). İş tatmini, bireyin yaptığı işe karşı olumlu bir tutum sergilemesi şeklinde ifade edilmektedir (İşcan ve Sayın, 2010).

\section{4. Örgütsel Öğrenme, Örgütsel Vatandaşlık Davranışı ve İş Tatmini İlişkisi}

Yerli ve yabancı yazın taranması sonucunda araştırma değişkenleri olarak ifade edilen örgütsel öğrenme, örgütsel vatandaşlık davranışı ve iş tatmini arasındaki ilişkiyi akademisyenler çerçevesinde ele alan çalışmaya rastlanmamıştır. Bununla birlikte, yerli ve yabancı yazında örgütsel öğrenme ve örgütsel vatandaşlık davranışının iş tatmini üzerindeki etkilerini ayrı ayrı ele alan çalışmalar mevcuttur.

Arslantaş 2006 yılında yaptığı çalışmasında, bir işletmenin satış departmanında çalışan 44 beyaz yakalı üzerinde örgütsel öğrenmenin örgütsel vatandaşlık davranışı üzerindeki etkisini incelemiştir. Sonuç olarak, örgütsel öğrenme ve örgütsel vatandaşlık davranışı arasındaki ilişkinin pozitif olduğu görülmüştür. Ayrıca, örgütsel öğrenmenin boyutlarının örgütsel vatandaşlık davranışı boyutlarını anlamlı bir şekilde etkilediği görülmüştür.

Taşc1 ve Koç (2007), akademisyenlere yönelik örgütsel öğrenme ile örgütsel vatandaşlık davranışı ilişkisini incelemişlerdir. Sonuçlar, örgütsel vatandaşlık davranışının bazı boyutlarıyla örgütsel öğrenme değerleri arasındaki ilişkinin anlamlı olduğunu göstermiştir.

Basım vd. (2009), yapmış oldukları çalışmada öğrenen örgüt algısının örgütsel vatandaşlık davranışına etkisini incelemeyi amaçlamışlardır. Araştırmalarını 436 beyaz yakalı çalışan üzerinde yapmışlardır. Araştırma sonucunda, öğrenen örgüt algısı ile örgütsel vatandaşlık arasındaki ilişkinin pozitif olduğu ve örgütsel öğrenmenin kimi boyutlarının örgütsel vatandaşl1k üzerinde etkili olduğu görülmüştür.

Chang vd. (2011), yapmış oldukları çalışmada örgütsel vatandaşlık davranışları, örgütsel taahhütler ve örgütsel öğrenme etkileri arasındaki ilişkiyi incelemişlerdir. Araştırma sonucunda, örgütsel vatandaşlık davranışlarının ve örgütsel taahhütlerin örgütsel öğrenme etkilerini olumlu yönde etkilediği ve örgütsel vatandaşlık davranışlarının örgütsel taahhütlerden olumlu yönde etkilenebileceği görülmüştür.

Demirel ve Tohum 2018 yılında yaptıkları çalışmalarında, örgütsel öğrenmenin örgütsel vatandaşlık davranışı üzerindeki etkisini incelemişlerdir. Sonuçlar, örgütsel öğrenme 


\section{Tekin, E., Sırkıntıoğlu Yıldırım, Ş.}

ile örgütsel vatandaşlık davranışı arasındaki ilişkinin pozitif olduğunu ve örgütsel öğrenmenin örgütsel vatandaşlığ 1 olumlu yönde etkilediğini göstermiştir.

Çalışmada adı geçen örgütsel öğrenme ve iş tatmini değişkenine ilişkin geliştirilen hipotezler şu şekildedir: $\mathbf{H}_{1}$ : Akademisyenlerdeki örgütsel öğrenme ve alt boyutları $\left(\mathbf{H}_{\mathbf{1 a}}\right.$ deneyim $\mathbf{H}_{\mathbf{1 b}}$ : risk alma $\mathbf{H}_{\mathbf{1}}$ : dış çevre ile etkileşim $\mathbf{H}_{\mathbf{1 d}}$ : iletişim $\mathbf{H}_{\mathbf{1 e}}$ : katılımcı karar verme) iş tatmini üzerinde etkilidir.

Egan vd. (2004), yapmış oldukları çalışmada örgütsel öğrenme kültürü, iş tatmini ve örgütsel sonuç değişkenlerinin ABD'deki bir bilişsim teknolojisi çalışanı ile ilişkisini incelemişlerdir. Yapılan çalışmada, öğrenen örgütsel kültürünün, bilişim teknolojisi çalışanlarının iş tatmini ve öğrenmeyi aktarma motivasyonu ile ilişkili olduğu görülmüş ve işten ayrılma niyetinin örgütsel öğrenme kültüründen, iş tatmininden olumsuz yönde etkilendiği tespit edilmiştir.

Özer 2013 yılında yaptığı çalışmasında, özel hastanelerin örgütsel öğrenme düzeyleri ile sağlık profesyonellerinin iş tatminleri arasındaki ilişkiyi incelemeyi amaçlamıştır. Sonuç olarak, örgütsel öğrenme ile iş tatmini arasındaki ilişkinin pozitif yönlü olduğu ve örgütsel öğrenme düzeylerinin iş tatminini olumlu yönde etkilediği sonucuna ulaşmıştır.

Çalışmada adı geçen örgütsel vatandaşlık davranışı ile iş tatmini değişkenine ilişkin geliştirilen hipotezler şu şekildedir: $\mathbf{H}_{2}$ :Akademisyenlerdeki örgütsel vatandaşlık davranışı ve alt boyutları ( $\mathbf{H}_{2 \mathbf{a}}$ :diğergamlık $\mathbf{H}_{\mathbf{2 b}}$ : vicdanlıl1k $\mathbf{H}_{\mathbf{2 c}}$ : nezaket $\mathbf{H}_{2 \mathbf{d}}$ : centilmenlik $\mathbf{H}_{\mathbf{2 e}}$ sivil erdem) iş tatmini üzerinde etkilidir.

Tsai ve Wu (2010), örgütsel vatandaşlık davranışı, iş tatmini ve işten ayrılma niyeti arasındaki ilişkileri incelemişlerdir. Sonuç olarak, hemşirelerin iş doyumları ile örgütsel vatandaşlık davranışları arasında pozitif korelasyon olduğu görülmüştür.

Miao (2011), yapmış olduğu çalışmada Çin'de algılanan örgütsel destek ve iş tatmini ile örgütsel vatandaşlık davranışı ve görev performansı arasındaki ilişkiyi incelemeyi amaçlamıştır. Araştırma sonucunda, algılanan örgütsel destek ve iş tatmini ile görev performansı arasında ve iş tatmini ile örgütsel vatandaşlık davranışı arasında pozitif ilişki tespit edilmiştir.

Najafi vd. (2011), yapmış oldukları çalışmada iş tatmini ve örgütsel bağlılı̆̆ın aracı rolünü inceleyerek örgütsel adalet, psikolojik güçlendirme, örgütsel bağl1lık, iş tatmini ve örgütsel vatandaşlık davranışı arasındaki ilişskiyi araştırmışlardır. Araştırmanın sonucunda, örgütsel adalet, iş memnuniyetini ve psikolojik güçlendirmeyi, psikolojik güçlendirme, iş 
memnuniyetini ve psikolojik güçlenmeyi, iş tatmini, örgütsel bağl1lığı ve örgütsel vatandaşlık davranışını doğrudan etkilediği görülmüştür.

Literatürdeki çalışmalar incelendiğinde araştırmamızdaki değişkenlerin örgütsel öğrenme - örgütsel vatandaşlık, örgütsel öğrenme - iş tatmini, iş tatmini - örgütsel vatandaşlık şeklinde kavramlar arasında ikili ilişkilerin olduğu görülmüştür. Mevcut araştırmada ele alınan örgütsel öğrenme - örgütsel vatandaşlık davranışı - iş tatmini değişkenlerini üçünü birlikte ele alan çalışmalar incelendiğinde ise doğrudan ya da dolaylı olarak bir çalışmaya rastlanmamıştır. Çalışmanın bu anlamda araştırmacılara yol göstereceği, alan yazına katkıda bulunacağı düşüncesiyle örgütsel öğrenme ve örgütsel vatandaşlık davranışının iş tatmini üzerindeki etkileri çalışma kapsamında sunulacaktır. Bu bağlamda araştırmanın amacına ve yazına dayanarak oluşturulan araştırma modeli Şekil 1'de görülmektedir.

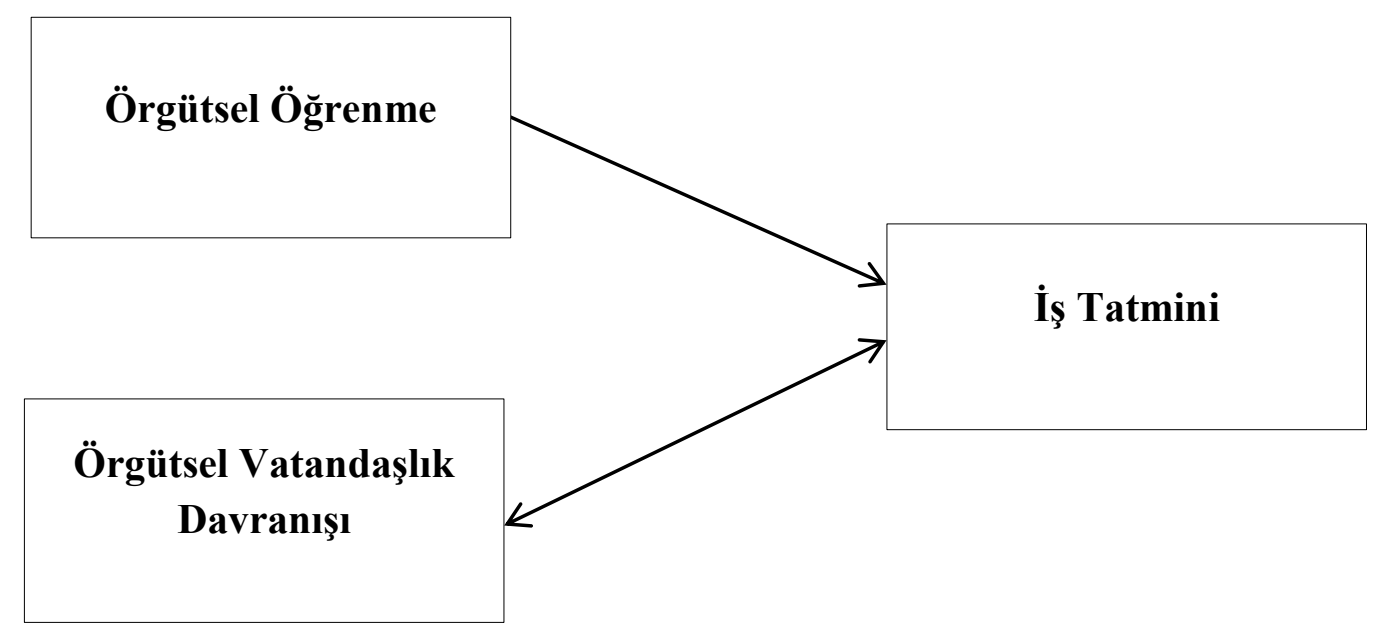

Şekil 1. Araştırma modeli

\section{ARAŞTIRMA METODOLOJISİ}

\subsection{Araştırma Örneklem ve Sınırlılıkları}

Araştırmanın evrenini Kastamonu ve Ankara ilinde bulunan üniversitelerdeki akademisyenler oluşturmaktadır. Kolayda örnekleme yöntemi kullanılarak araştırmanın örneklemi belirlenmiştir. Anket gönüllülük esasına dayalı olarak yapılıp, her bir akademisyen ile birebir görüşülerek anket formu doldurulmuştur. Toplamda 310 akademisyene ulaş1lmış olup, 256 akademisyen araştırmaya katılmayı kabul etmiştir. Anketler 2019 yılı Kasım Aralık aylarında toplanmıştır. Araştırma kapsamında akademisyenlerin iş yoğunluğu, ankete katılmak istememeleri, çalışmanın sadece Kastamonu ve Ankara ilinde bulunan üniversitelerdeki akademisyenleri kapsaması çalışmanın sınırlılıklarını oluşturmaktadır. 


\subsection{Veri Toplama Yöntemi ve Araçları}

Anket formunda dört bölüm ve 43 adet soru yer almaktadır. İlk bölümde akademisyenlerin demografik özelliklerini belirmek amacıyla beş soru sorulmuştur. İkinci bölümde 14 ifadeden oluşan Chiva ve Alegre'nin (2009) geliştirip, Aydoğan ve arkadaşları (2011) tarafından Türkçe'ye çevrilen beş faktörlü (deneyim, risk alma, dış çevre ile etkileşim, iletişim ve katılımcı karar verme) örgütsel öğrenme ölçeği kullanılmıştır. Ölçeğin güvenilirlik katsayısı 0.93 olarak belirlenmiştir. Üçüncü bölümde 19 ifadeden oluşan Organ'ın (1988) geliştirip, Basım ve Şeşen'in (2006) Türkçe'ye çevirdiği beş faktörlü (diğergamlık, vicdanlılık, nezaket, centilmenlik ve sivil erdem) örgütsel vatandaşlık davranışı ölçeği kullanılmıştır. Ölçeğin güvenilirlik katsayısı 0.80 olarak belirlenmiştir. Anketin dördüncü bölümünde beş ifadeden oluşan Hackman ve Oldham'ın (1975) geliştirdiği, tek boyutlu iş tatmini ölçeği kullanılmıştır. Ölçekte yer alan ifadeler yazarlar tarafından Türkçe'ye çevrilmiş olup, anlam bütünlüğünün bozulmasını önlemek amacıyla iki akademisyene kontrol ettirilmiştir. Ölçekte yer alan ifadeler beşli Likert ölçeği kullanılarak ölçülmüştür.

\subsection{Araştırma Verilerinin Analizi}

Çalışmada öncelikle tanımlayıcı istatistiklere yer verilmiştir. Daha sonra örneklemin yeterliliğini test etmek amaciyla, Kaiser-Meyer-Olkin değeri ve Barlett test ölçütü incelemesi yapılmıştır. Araştırmada kullanılan ölçeklerde bulunan soruların geçerliliğini test etmek için, faktör analizi yapılmış ve faktör yapıları tespit edilmiştir. Son olarak araştırma kapsamında oluşturulan hipotezlerin ve modelin test edilmesi için regresyon analizlerine yer verilmiştir. 


\section{BULGULAR}

\subsection{Tanımlayıcı Bulgular}

Örneklemde yer alan çalışanlara ilişkin bulgular Tablo 1'de görülmektedir.

Tablo 1. Katılımcılara ilişkin tanımlayıcı bulgular

\begin{tabular}{|c|c|c|c|}
\hline Değişkenler & Gruplar & Frekans & Yüzde (\%) \\
\hline \multirow{2}{*}{ Cinsiyet } & Kadın & 118 & 46,1 \\
\hline & Erkek & 138 & 53,9 \\
\hline \multirow{5}{*}{ Yaş } & $20-30$ aras1 & 92 & 35,9 \\
\hline & $31-40$ aras1 & 114 & 44,5 \\
\hline & $41-50$ aras 1 & 38 & 14,8 \\
\hline & $51-60$ aras1 & 10 & 3,9 \\
\hline & 61 ve üzeri & 2 & 0,8 \\
\hline \multirow{3}{*}{ Eğitim düzeyi } & Lisans & 14 & 5,5 \\
\hline & Yüksek Lisans & 78 & 30,5 \\
\hline & Doktora & 164 & 64,1 \\
\hline \multirow{6}{*}{ İş yeri deneyimi } & 3 y1l ve alt1 & 72 & 28,1 \\
\hline & 4-7 y1l aras1 & 105 & 41,0 \\
\hline & 8-11 yıl aras1 & 62 & 24,2 \\
\hline & $12-15$ yıl aras1 & 4 & 1,6 \\
\hline & 16-19 y1l aras1 & 5 & 2,0 \\
\hline & 20 yıl ve üzeri & 8 & 3,1 \\
\hline \multirow{6}{*}{ Toplam deneyim } & 3 y1l ve alt1 & 32 & 12,5 \\
\hline & 4-7 y1l aras1 & 68 & 26,6 \\
\hline & $8-11$ y1l aras1 & 90 & 35,2 \\
\hline & $12-15$ y1l aras1 & 26 & 10,2 \\
\hline & 16-19 y11 aras1 & 9 & 3,5 \\
\hline & 20 y1l ve üzeri & 31 & 12,1 \\
\hline Toplam & & 256 & 100 \\
\hline
\end{tabular}

Tablo 1 incelendiğinde, çalışmaya katılan akademisyenlerin \%53,9’u erkeklerden oluşmaktadır. Katılımcılar yaş aralığı açısından incelendiğinde, en fazla katılımcıya sahip olan yaş grubun $(\% 44,5)$ 31-40 yaş arası olduğu görülmektedir. Katılımcılar eğitim düzeyi yönünden incelendiğinde, doktora mezunlarının oluşturduğu grubun $(\% 64,1)$ en yoğun grup olduğu görülmektedir. Katılımcılar iş yeri deneyimi yönünden incelendiğinde en fazla katılımcının sahip olduğu grup (\%41,0) 4-7 yıldır çalışanlar şeklindedir. Katılımcılar toplam iş deneyimi yönünden incelendiğinde ise en fazla katılımcının sahip olduğu grup $(\% 35,2) 8$ 11 yıl arası çalışma hayatında olanlar şeklindedir.

\subsection{Faktör Analizi Bulguları}

Faktör analizine başlamadan önce örneklemin yeterliliğini test etmek amacıyla gözlenen ile kısmi korelasyon katsayılarının büyüklüğünü karşılaştıran bir indeks olan KaiserMeyer-Olkin test ölçütü incelenmiştir. KMO oranı $(0,500)$ üzerindeyse, örneklemin yeterli olduğu ifade edilmektedir. Ayrıca KMO oranı ne kadar yüksekse, veri seti faktör analizi için o kadar anlamlıdır (Kalaycı, 2010). Yapılan analizler sonucunda, örgütsel öğrenme ölçeği için çıkan KMO örneklem yeterliliği değeri 0,930 mükemmel olarak değerlendirilmekte ve KMO 


\section{Tekin, E., Sırkıntıoğlu Yıldırım, Ş.}

değeri $(0,500)$ üzerinde olmalıdır şartını sağladığından dolayı ölçek faktör analizine uygundur.

Örgütsel öğrenme ölçeğinin faktör yapısını belirlemek amacıyla, soru formunda yer alan ilgili sorulara Varimax rotasyonu temel bileşenler faktör analizi yapılmıştır. Elde edilen faktör analizi sonucunda ölçekteki üçüncü ifade (ÖÖ3) faktör yükü, Ergin (2014) tarafından belirtilen alt sınırın (0.50) altında olduğundan dolayı analizden çıkarılmıştır.

Yapılan faktör analizi sonucunda, faktörlerin açıklama düzeyinin \% 79,076 olduğu ve toplam beş faktörde toplandığ1 görülmüştür. Bu bağlamda deneyim faktörü ÖÖ1, ÖÖ2 olmak üzere iki sorudan oluşmaktadır ve faktör yüklerinin $(0,734 ; 0,730)$ açıklanan varyansı \%20,537'dir. Risk alma faktörü ÖÖ3 ve ÖÖ4 olmak üzere iki sorudan oluşmaktadır ve faktör yüklerinin $(0,821)$ açıklanan varyansı \%19,704'tür. Dış çevre ile etkileşim faktörü ÖÖ5, ÖÖ6, ÖÖ7 olmak üzere üç sorudan oluşmaktadır ve faktör yüklerinin $(0,818 ; 0,729 ; 0,582)$ açıklanan varyansı \%14,943'tür. İletişim faktörü ÖÖ8, ÖÖ9, ÖÖ10, ÖÖ11 olmak üzere dört sorudan oluşmaktadır ve faktör yüklerinin $(0,658 ; 0,641 ; 0,776 ; 0,638)$ açıklanan varyansı \%14,882'dir. Son olarak katılımcı karar verme faktörü ÖÖ12, ÖÖ13, ÖÖ14 olmak üzere üç sorudan oluşmaktadır ve faktör yüklerinin $(0,805 ; 0,851 ; 0,813)$ açıklanan varyansı $\% 9,009$ 'dur.

Örgütsel vatandaşlık davranışı ölçeğinin faktör yapısını belirlemek amacıyla, soru formunda yer alan ilgili sorulara Varimax rotasyonu temel bileşenler faktör analizi yapılmıştır. Elde edilen faktör analizi sonucunda, ölçekteki ÖVD4, ÖVD5, ÖVD7, ÖVD15 analizden çıkarılmıştır.

Yapılan faktör analizi sonucunda, faktörlerin açıklama düzeyinin \% 65,761 olduğu ve toplam beş faktör altında toplandığı görülmüştür. Bu bağlamda diğergamlık faktörü ÖVD1, ÖVD2, ÖVD3, ÖVD4, ÖVD5 olmak üzere beş sorudan oluşmaktadır ve faktör yüklerinin $(0,857 ; 0,814 ; 0,528)$ açıklanan varyansı \%16,011'dir. Vicdanlılık faktörü ÖVD6, ÖVD7, ÖVD8 olmak üzere üç sorudan oluşmaktadır ve faktör yüklerinin $(0,521 ; 0,853)$ açıklanan varyans1 \%15,910'dur. Nezaket faktörü ÖVD9, ÖVD10, ÖVD11 olmak üzere üç sorudan oluşmaktadır ve faktör yüklerinin $(0,794 ; 0,765 ; 0,800)$ açıklanan varyansı \%13,154'tür. Centilmenlik faktörü ÖVD12, ÖVD13, ÖVD14, ÖVD15 olmak üzere dört sorudan oluşmaktadır ve faktör yüklerinin $(0,671 ; 0,750 ; 0,774)$ açıklanan varyansı $\% 11,797$ 'dir. Son olarak sivil erdem faktörü ÖVD16, ÖVD17, ÖVD18, ÖVD19 olmak üzere dört sorudan oluşmaktadır ve faktör yüklerinin $(0,679 ; 0,773 ; 0,690 ; 0,653)$ açıklanan varyansı $\% 8,888^{\prime}$ dir. 
İş tatmini ölçeğinin faktör yapısını belirlemek amacıyla, soru formunda yer alan ilgili sorulara Varimax rotasyonu temel bileşenler faktör analizi yapılmıştır. Yapılan faktör analizi sonucunda, faktörlerin $(0,813 ; 0,872 ; 0,921 ; 0,846 ; 0,638)$ açıklama düzeyinin $\% 67,852$ olduğu ve ölçeğin tek faktör altında toplandığı görülmüştür. Bu bağlamda iş tatmini faktörü İT1-İT5 olmak üzere beş sorudan oluşmaktadır.

Faktör analizlerinden sonra değişkenlerin dağılımlarının biçimlerini ortaya çıkarmak, verilerin normal dağılıp dağılmadığına bakmak için analizler yapılmıştır. Bulgular Tablo 2'de görülmektedir.

Tablo 2. Kullanılan ölçeklere ilişkin normallik değerleri tablosu

\begin{tabular}{lcccc}
\hline $\begin{array}{l}\text { Değişkenler ve } \\
\text { Boyutlar }\end{array}$ & Ortalama & Std. Sapma & Çarpıklık & Basıklık \\
\hline $\begin{array}{l}\text { Örgüitsel } \\
\text { öğrenme }\end{array}$ & 3,03 & 0,78 & 0,05 & $-0,24$ \\
\hline Deneyim & 3,23 & 0,96 & $-0,21$ & $-0,41$ \\
\hline Risk alma & 3,12 & 1,04 & $-0,08$ & $-0,67$ \\
\hline $\begin{array}{l}\text { Dış çevre ile } \\
\text { etkileşim }\end{array}$ & 3,04 & 0,86 & $-0,12$ & $-0,31$ \\
\hline İletişim & 3,22 & 0,87 & $-0,21$ & $-0,10$ \\
\hline $\begin{array}{l}\text { Katılımcı karar } \\
\text { verme }\end{array}$ & 2,63 & 1,08 & 0,26 & $-0,73$ \\
\hline $\begin{array}{l}\text { Örgüitsel vat. } \\
\text { davranışı }\end{array}$ & 3,92 & 0,46 & $-0,42$ & 1,59 \\
\hline Diğergamlık & 3,92 & 0,46 & $-0,42$ & 1,59 \\
\hline Vicdanlılı & 3,75 & 0,68 & $-0,24$ & 0,02 \\
\hline Nezaket & 4,48 & 0,55 & $-1,44$ & 3,81 \\
\hline Centilmenlik & 3,77 & 0,74 & $-0,38$ & $-0,18$ \\
\hline Sivil erdem & 3,83 & 0,69 & $-0,58$ & 0,97 \\
\hline İş Tatmini & 3,88 & 0,84 & $-0,86$ & 0,85 \\
\hline
\end{tabular}

Sosyal bilimler alanında normallik testlerinden daha çok değişkenlere ilişkin verilerin normal dağılıp dağılmadığına yönelik olan çarpıklık (skewness) ve basıklık (kurtosis) değerlerine bakmak daha doğrudur (Kara, 2019). George ve Mallery’e (2010) göre çarpıklık ve basıklık değerlerinin -2 ile +2 aralığında yer alması verilerin normal dağıldığını göstermektedir. Yapılan analiz sonucunda (nezaket boyutu hariç) verilerin normal dağıldığı görülmektedir.

Aşağıdaki tabloda örgütsel öğrenme-alt boyutları, örgütsel vatandaşlık davranışı-alt boyutları ve iş tatmini için Cronbach's Alpha değerleri görülmektedir. 
Tekin, E., Sırkıntıŏglu Yıldırım, Ş.

Tablo 3. Güvenilirlik analizleri

\begin{tabular}{lcc}
\hline \multicolumn{1}{c}{ Değişkenler ve Boyutlar } & Cronbach's Alfa & Örneklem Sayısı \\
\hline Örgütsel Öğrenme &, 859 & 256 \\
\hline Deneyim &, 865 & 256 \\
\hline Risk alma &, 882 & 256 \\
\hline Dış çevre ile etkileşim &, 873 & 256 \\
\hline İletişim &, 866 & 256 \\
\hline Katılımcı karar verme &, 870 & 256 \\
\hline Örgütsel Vat. Davranıșı &, 874 & 256 \\
\hline Diğergamlık &, 874 & 256 \\
\hline Vicdanlılık &, 885 & 256 \\
\hline Nezaket &, 883 & 256 \\
\hline Centilmenlik &, 876 & 256 \\
\hline Sivil erdem &, 873 & 256 \\
\hline İș Tatmini &, 890 & 256 \\
\hline
\end{tabular}

Araştırma kapsamında ele alınan değişkenlerin güvenirliklerini incelediğimizde örgütsel öğrenme için 0,859 bulunan değer sonucunda ölçeğin güvenilir olduğu söylenebilir. Örgütsel vatandaşlık davranışı için Cronbach's Alpha değeri 0,874 olarak tespit edilmiştir ve güvenilirdir. Son olarak iş tatmini ölçeği için Cronbach's Alpha değeri 0,890 olarak belirlenmiştir ve bu değer sonucunda ölçeğin güvenilir olduğu söylenebilir. Tablo 3 'te her bir alt boyut için Cronbach's Alpha değerlerine yer verilmiştir.

Normallik değerlerine bakıldıktan sonra çalışma kapsamında oluşturulan hipotezler analiz edilmiştir. Bu kapsamda ilk olarak örgütsel öğrenmenin iş tatmini üzerindeki etkisini belirleyen regresyon analizi tablosuna, daha sonra örgütsel öğrenme boyutlarının iş tatmini üzerindeki etkisini inceleyen regresyon analizi tablosuna, örgütsel vatandaşlık davranışının iş tatmini üzerindeki etkisini inceleyen regresyon analizi tablosuna ve son olarak örgütsel vatandaşlık davranışı alt boyutlarının iş tatmini üzerindeki etkisini inceleyen regresyon analizi tablosuna yer verilmiştir. Bu bağlamda yapılan analizde elde edilen sonuçlar Tablo 4, 5, 6 ve 7'de sunulmuştur.

Tablo 4. Örgütsel öğrenme ve iş tatminine ilişkin regresyon analizleri

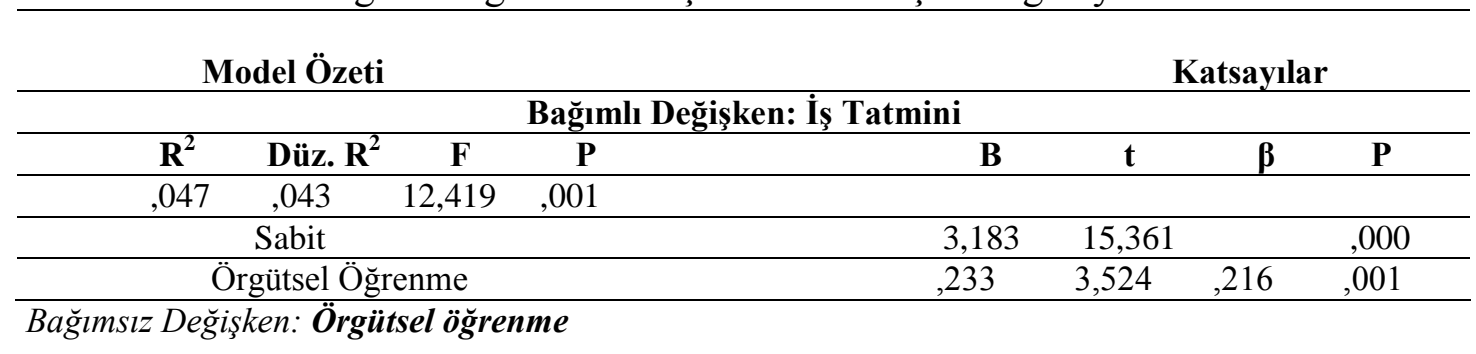

Tablo 4'de yer alan analiz sonucuna göre model istatistiksel açıdan ( $F=12,419$, $\mathrm{P}<0,01$ ) anlamlı çıkmış ve iş tatminindeki değişimi \% 4,3 (Düzeltilmiş $\mathrm{R}^{2}=0,043$ ) seviyesinde açıklamaktadır. Bağımsız değişken olan örgütsel öğrenmenin $(\beta=, 216 ; p<.01)$ iş tatmini pozitif ve anlamlı bir şekilde etkilediği tespit edilmiştir. Elde edilen sonuçlar $\mathrm{H}_{1}$ hipotezinin doğrulandığını göstermektedir. 
Tablo 5. Örgütsel öğrenme boyutları ve iş tatminine ilişkin regresyon analizleri

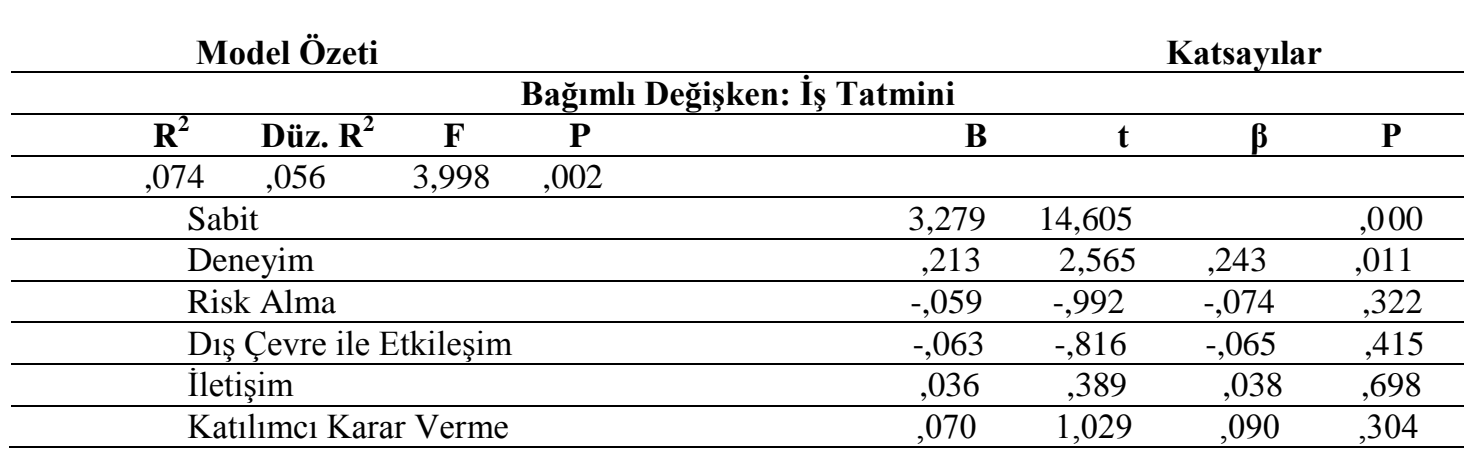

Bă̆ımsız Değişkenler: Deneyim, risk alma, dış çevre ile etkileşim, iletişim, katılımcı karar verme

Tablo 5'de yer alan analiz sonucuna göre, model istatistiksel açıdan $(\mathrm{F}=3,998, \mathrm{P}<0,02)$ anlamlı çıkmış ve iş tatminindeki değişimi \% 5,6 (Düzeltilmiş R2=0,056) seviyesinde açıklamaktadır. Bağımsız değişkenlerden deneyim $(\beta=, 243 ; \mathrm{p}<.05)$ boyutunun, bağımlı değişken iş tatminini pozitif ve anlamlı bir şekilde etkilediği tespit edilmiştir. Bağımsız değişkenlerden risk alma, dış çevre ile etkileşim, iletişim ve katılımcı karar vermenin, bağımlı değişken iş tatminini anlamlı bir etkisinin olmadığı görülmüştür. Elde edilen sonuçlar öne sürülen $\mathrm{H}_{1 \mathrm{a}}$ hipotezini desteklemiş, $\mathrm{H}_{1 \mathrm{~b}}, \mathrm{H}_{1 \mathrm{c}}, \mathrm{H}_{1 \mathrm{~d}}$ ve $\mathrm{H}_{1 \mathrm{e}}$ hipotezlerini ise desteklememiştir.

Tablo 6. Örgütsel vatandaşlık davranışı ve iş tatminine ilişkin regresyon analizleri

\begin{tabular}{|c|c|c|c|c|c|c|c|}
\hline \multicolumn{3}{|c|}{ Model Özeti } & & & \multicolumn{3}{|c|}{ Katsayılar } \\
\hline \multicolumn{8}{|c|}{ Bağımlı Değişken: İș Tatmini } \\
\hline $\mathbf{R}^{2}$ & Düz. $\mathbf{R}^{2}$ & $\mathbf{F}$ & $\mathbf{P}$ & $\mathbf{B}$ & $\mathbf{t}$ & $\boldsymbol{\beta}$ & $\mathbf{P}$ \\
\hline, 067 &, 064 & 18,303 & 000 & & & & \\
\hline \multicolumn{4}{|c|}{ Sabit } & 2,051 & 4,740 & & ,000 \\
\hline \multicolumn{4}{|c|}{ Örgütsel Vatandaşlık Davranıșı } & ,468 & 4,278 & 259 &, 000 \\
\hline
\end{tabular}

Tablo 6'da yer alan analiz sonucuna göre model istatistik açıdan $(\mathrm{F}=18,303, \mathrm{P}<0,00)$ anlamlı çıkmış ve iş tatminindeki değişimi \%6,4 (Düzeltilmiş $\mathrm{R}^{2}=0,064$ ) seviyesinde açıklamaktadır. Bağımsız değişken olan örgütsel vatandaşlık davranışının $(\beta=, 259 ; p<.01)$ iş tatminini pozitif ve anlamlı bir şekilde etkilediği tespit edilmiştir. Elde edilen sonuçlar öne sürülen $\mathrm{H}_{2}$ hipotezini desteklemiştir. 
Tablo 7. Örgütsel vatandaşlık davranışı boyutları ve iş tatminine ilişkin regresyon analizleri

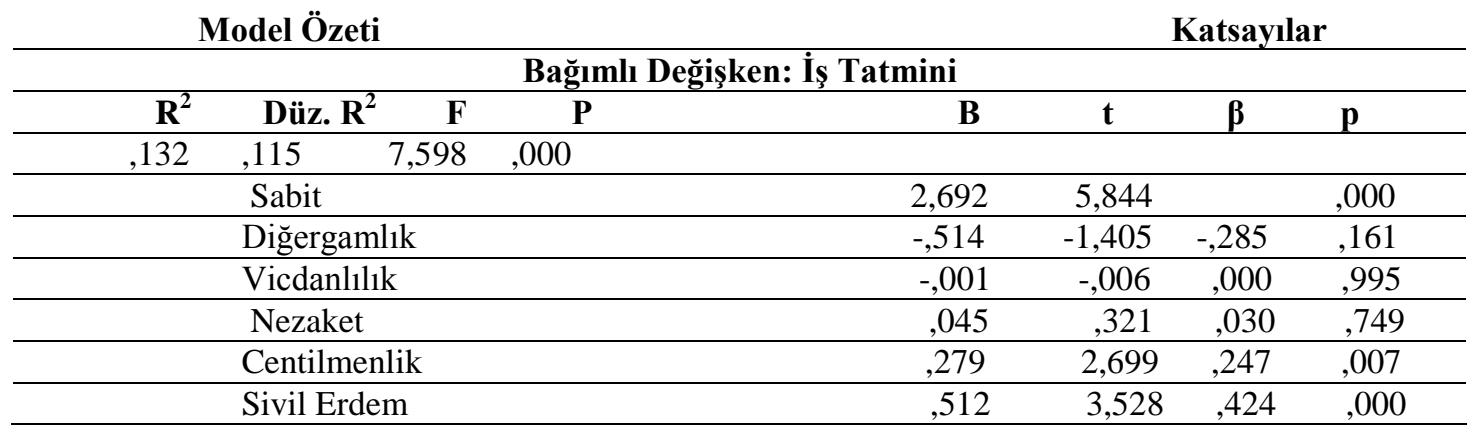

Bă̆ımsız, Değişkenler: Dĭgergamlık, vicdanlılık, nezaket, centilmenlik, sivil erdem

Tablo 7'de yer alan analiz sonucuna göre model istatistiksel açıdan $(\mathrm{F}=7,598, \mathrm{P}<0,00)$ anlamlı çıkmış ve iş tatminindeki değişimi \% 11,5 (Düzeltilmiş $\mathrm{R} 2=0,115$ ) seviyesinde açıklamaktadır. Bağımsız değişkenlerden centilmenlik $(\beta=, 247 ; \mathrm{p}<.01)$, sivil erdem $(\beta=, 424$; $\mathrm{p}<.01$ ) boyutlarının, bağımlı değişken iş tatminini pozitif ve anlamlı bir şekilde etkilediği tespit edilmiştir. Bağımsız değişkenlerden diğergamlık, vicdanlılık ve nezaketin, bağımlı değişken iş tatminini anlamlı bir etkisinin olmadığı görülmüştür. Elde edilen sonuçlar öne sürülen $\mathrm{H}_{2 \mathrm{~d}}$ ve $\mathrm{H}_{2 \mathrm{e}}$ hipotezlerini desteklemiş, $\mathrm{H}_{2 \mathrm{a}}, \mathrm{H}_{2 \mathrm{~b}}$ ve $\mathrm{H}_{2 \mathrm{c}}$ hipotezlerini ise desteklememiştir.

\section{SONUÇ VE ÖNERÍLER}

Küresel rekabetin yoğun olduğu, sürekli ve hızlı değişim gösteren dinamik bir ortamda varlıklarını devam ettirmek isteyen işletmeler öğrenmeye gereksinim duymaktadır. Öğrenme, istenilen duruma gelinebilmesi için ömür boyu devam eden bilgi edinme sürecidir. Öğrenilenlerin işle ilgili olması, uygulanabilir olması veya geri dönüşümünün olması durumunda örgütsel öğrenme meydana gelmektedir. Örgütsel öğrenme örgütlerde daha ilerlemiş bilgi anlama biçimiyle davranışların ve faaliyetlerin iyileştirilmesi olarak tanımlanmaktadır. Örneğin, hamarat kişi yaptığı işten dolayı davranışlarının olumlu etkileneceğini bilirse isteği artar ve üretimini arttırır. Bunun aksine iyileştirilmeyen davranışlar zayıflayıp zamanla eksilecektir. İyileştirme ve sönme, insan davranışının kontrolünde ve öğrenmeyi elde etmede seçkin bir araçtır (Ceylan, 2012). Bir örgütün öğrenebilmesi için önce örgütü oluşturan bireylerin öğrenmesi gerekir. Daha sonra bireyin oluşturduğu gruplar arasında öğrenilen bilgiler tartışılacak, bir değerlendirme yapılacaktır. Bu aşamadan sonra örgütsel öğrenme sürecine geçilecektir. Bunun yanı sıra bir örgütün ayakta kalabilmesi için öğrenme kadar önemli olan örgütsel vatandaşlık davranışıdır. Örgütsel vatandaşlık davranışı literatürde de ifade edildiği gibi biçimsel rol davranışlarının dışında isteğe bağlı gerçekleştirilen örgütsel başarıya katkıda bulunan davranışlardır (Demirel ve 
Tohum, 2018). Çalışanların isteğe bağlı örgütsel vatandaşlık davranışı sergilemeleri, gerek işletmeler açısından gerek ülkeler açısından olumlu sonuçlar doğurmaktadır. Şöyle ki, örgütlerde işe gelmeyen çalışanın işlerini yapma, iş yükü ağır olan çalışana yardımcı olma, oluşabilecek herhangi bir soruna karşı diğer çalışanı uyarma, çalışma ortamında daima hoşgörülü olma gibi davranışlar çalışanların tatmin seviyesini etkilemektedir. Çalışanların örgütsel vatandaşlık davranışı düzeylerindeki artış iş tatmini düzeyinde de artışa sebep olmaktadır. Yani çalışanlar iş yerine yönelik olumlu davranış sergilediklerinde iş tatmini de bu davranıştan olumlu etkilenecektir (Demirel ve Özçınar, 2009). Ayrıca işinden tatmin olan çalışanların örgütsel vatandaşlık davranışı sergileyeceği ve bu durumunda işletmeye olumlu yansıyacağı düşünülmektedir. Örneğin, işinden umduğu tatmini sağlayan çalışan herhangi bir zorlama olmadan, çalıştığı iş arkadaşlarını oluşabilecek sorunlara karşı haberdar etme, işine ve çalışanlara karşı daha hoşgörülü olma gibi isteğe bağlı davranışlar göstermektedir (Yeşilyurt ve Koçak, 2014).

$\mathrm{Bu}$ çalışmasının temel amacı, örgütsel öğrenme ve örgütsel vatandaşlık davranışının iş tatmini üzerindeki etkisini incelemektir. Araştırma kapsamında yapılan regresyon analizleri sonucunda örgütsel öğrenme boyutlarından deneyim boyutunun iş tatminini pozitif ve anlamlı bir şekilde etkilediği görülmüştür. İşletmeler çalışanların, işlerine karşı olumlu duygular beslemelerini isterlerse çalışanların düşüncelerine önem vermeli ve yeni fikirleri deneme isteğine açık olmalıdırlar. Çünkü fikirlerinin önemsendiğini hisseden çalışan işine daha sıkı sarılacak ve sonucunda o işten tatmin olma düzeyi artacaktır.

Örgütsel öğrenme boyutlarından risk alma, dış çevre ile etkileşim, iletişim ve katılımcı karar verme boyutunun iş tatmini üzerinde etkisine rastlanılmamıştır. $\mathrm{Bu}$ da örgütsel öğrenmenin iş tatmini üzerinde kısmen etkili olduğunu göstermektedir.

Örgütsel vatandaşlık davranışı boyutlarından centilmenlik ve sivil erdem boyutunun iş tatminini pozitif ve anlamlı bir şekilde etkilediği görülmüştür. İşletmelerde arkadaşlarına kaba davranmayan, olumsuz durumlarda dahi pozitif düşünen çalışan davranışları iş tatminine olumlu yansımaktadır. Literatür incelendiğinde örgütsel vatandaşlık davranışı boyutlarının iş tatmini üzerindeki etkisini direkt ele alan bir çalışmaya rastlanılmaması çalışmayı önemli kılmaktadır. Ayrıca literatüre bakıldığında Demir'in (2015) çalışmasında örgütsel vatandaşlık davranışı boyutlarından centilmenlik ve sivil erdem boyutunun iş tatmini üzerinde etkili olması bu sonucu destekler niteliktedir. Ayrıca örgütsel vatandaşlık davranışının centilmenlik ve sivil erdem boyutunun iş tatminini etkilemesi dışında birey çalıştı̆ğ ortamda bir gün her şeyin iyiye gideceğini düşünerek kendi içsel tatminini de oluşturabilmektedir. 
Örgütsel vatandaşlık davranışı boyutlarından diğergamlık, vicdanlılık ve nezaket boyutunun iş tatmini üzerinde etkisine rastlanılmamıştır. $\mathrm{Bu}$ da örgütsel vatandaşlık davranışının iş tatmini üzerinde kısmen etkili olduğunu göstermektedir.

Sonuç olarak, örgütsel öğrenme ve örgütsel vatandaşlık davranışının iş tatmini üzerinde pozitif ve anlamlı bir etkisinin olduğu görülmüştür. Literatürde Demir (2015), yapmış olduğu çalışmasında örgütsel vatandaşlık davranışı ile iş tatmini arasındaki ilişkiyi incelemiştir. Araştırma sonucunda, örgütsel vatandaşlık davranışı ile iş tatmini arasındaki ilişkinin pozitif olduğu görülmüştür ve örgütsel vatandaşlık davranışının iş tatmini üzerinde pozitif etkisi saptanmıştır. Rose vd. (2009), örgütsel öğrenmenin iş tatmini üzerindeki etkisini incelemişlerdir. Araştırma sonuçlarına göre örgütsel öğrenme, örgütsel bağlılık, iş tatmini ve iş performansı arasındaki ilişkilerin pozitif olduğu görülmüştür. Ayrıca araştırmanın bu bulgusu, literatürde Özer (2013), Mert (2010), Egan (2004), Tsai ve Wu (2010) ve Najafi (2011) tarafindan yapılan çalışmalar ile de paralellik göstermektedir.

Çalışmanın bazı kısıtları bulunmaktadır. Araştırma kapsamında akademisyenlerin iş yoğunluğu, ankete katılmak istememeleri, çalışmanın sadece Kastamonu ve Ankara ilinde bulunan üniversitelerdeki akademisyenleri kapsaması çalışmanın sınırlılıklarını oluşturmaktadir.

Bu çalışmanın sonucunda, örgütsel öğrenmenin ve örgütsel vatandaşlık davranışının iş tatmini üzerinde etkili olduğu görülmüştür ve elde edilen sonuçlar bağlamında aşağıdaki öneriler sunulmuştur.

- Örgütlerde öğrenmeyi ve vatandaşlığı geliştirici yollar izlenebilir. Örneğin, bireylerin kendilerini rahat ifade edebilecekleri, deneyim ve tecrübelerini paylaşabilecekleri ortamlar yaratılabilir. Biz duygusuna önem verilerek, örgütsel vatandaşlık davranışına katkı sağlanabilir.

- Çalışanların fikirleri önemsenmeli, örgütlerde onların düşüncelerine de yer verilebilir.

- Örgütlerde sıcak bir çalışma ortamı sağlanarak çalışanların birbirine karşı rahat ve dürüst davranışlar sergilemesi sağlanabilir.

- Örgütler, bireylerin iş hakkında kendilerini geliştirmeleri için firsatlar sunabilir.

- $\mathrm{Bu}$ çalışma akademisyenler üzerinde örgütsel öğrenme ve örgütsel vatandaşlık davranışının iş tatmini üzerindeki etkisini incelemek amacıyla yapılmıştır. Literatür incelendiğinde akademisyenler üzerinde bu konuyu ele alan yalnızca birkaç çalışmaya rastlanmaktadır. Farklı sektörler ele alınarak, karşılaştırmalı çalışmalar yapılabilir. 
- $\mathrm{Bu}$ araştırmanın evrenini Ankara, Gazi ve Kastamonu üniversitelerinde bulunan akademisyenler oluşturmaktadır. Elde edilen sonuçlar genellemez. İleride yapılacak olan çalışmalar için ülke genelinde daha fazla akademisyeni kapsayacak şekilde üniversiteler arasında karşılaştırma yapılabilir.

\section{KAYNAKÇA}

Aksoytürk, G. (2008). Örgütsel kültürünün örgütsel öğrenme üzerine etkisi. Yayınlanmamış yüksek lisans tezi, Marmara Üniversitesi, İstanbul.

Alanoğlu, M. (2014). Ortaöğretim kurumlarının örgütsel öğrenme düzeylerinin okul etkililiği ve örgütsel vatandaşlık davranışlarına etkisi. Yayınlanmamış yüksek lisans tezi, Fırat Üniversitesi, Elazı ̆̆.

Allison, B. J. (2001). Student classroom and career success: the role of organizational citizenship behavior. Journal of Educational for Business, (5), 284-290.

Aquino, K. \& Bommer, W. (2003). Preferential mistreatment. How victim status moderates the relationship between organizational citizenship behavior and workplace victimization. Organization Science, (4), 374-385.

Arslantaş, C. C. (2006). Örgütsel öğrenmenin örgütsel vatandaşlık davranışı üzerindeki etkisini belirlemeye yönelik bir araştırma. GÜ İIBF Dergisi, (3), 153-170.

Atalay, İ. (2005). Örgütsel vatandaşlık ve örgütsel adalet. Yayınlanmamış yüksek lisans tezi, Afyon Kocatepe Üniversitesi, Afyonkarahisar.

Aydoğan, E. Orhan, F. Naldöken, Ü. Beylik, U. \& Aksay K. (2011). Sağlık kurumlarında örgütsel ögrenme kapasitesi: bir kamu hastanesi örneği. İktisadi ve Idari Bilimler Dergisi, (2), 191-213.

Barutçugil, İ. (2004). Stratejik Insan Kaynakları Yönetimi. İstanbul: Kariyer Yayınları.

Bateman, T. S. \& Organ, D. W. (1983). Job satisfaction and the good soldier: the relationship between affect and employee citizenship. Academiy of Management Journal, (4), 587-595.

Basım, N. H. \& Şeşen, H. (2006). İşletmelerin verimlilik ve etkililiğini arttırmada örgütsel vatandaşlık davranışı: büyük ölçekli işletmeler ve kobi'ler üzerine karşılaştırmalı bir araştırma. İsletme ve Finans Dergisi, (21), 92-100.

Basım, N. H. Şeşen, H. Sözen, C. \& Hazır, K. (2009). Çalışanların öğrenen örgüt algısının örgütsel vatandaşlık davranışlarına etkisi. Sosyal Bilimler Enstitüsü Dergisi, (22), 55-66.

Chang, C. C. Tsai, M. C. \& Tsai, M. S. (2011). The organizational citizenship behaviors and organizational commitments of organizational members influences the effects of organizational learning. International Journal of Trade Economics and Finance, (1), 61-66.

Chiva, R. \& Alegre, J. (2008). Emotional intelligence and job satisfaction: the role of organizational learning capability. Personel Review, (6), 680-701.

Chiva, R. \& Alegre, J. (2009). Organizational learning capability and job satisfaction: an empirical assesment in the ceramic tile industry. British Journal of Management, (20), 323340. 
Curry, C. D. (2016). Exploring vertical and horizontal dumensions of individualism and collectivism as predictors of organizational citizenship behavior. Doctoral dissertatio, Barry Üniversity, USA.

Cyert, R. M. \& March, J. G. (1963). A behavioral theory of the firm. Englewood Cliffs, NJ, (4), 169-187.

Çetin, C. (2004). İnsan Kaynaklarının Ĕgitim ve Gelişimi. İstanbul: Seçkin Yayınları.

Deluga, R. J. (1995). The relation between trust in the supervisorand subordinate organizational citizenship behavior. Military Psychology, (1), 1-16.

Demir, E. (2015). Örgütsel vatandaşlık davranışı ve iş tatmini ilişkisi: eğitim sektörü üzerine bir araştırma. Yayınlanmamış yüksek lisans tezi, Türk Hava Kurumu Üniversitesi, Ankara.

Demirel, Y. \& Özçınar, M. F. (2009). Örgütsel vatandaşlık davranışının iş tatmini üzerine etkisi: farklı sektörlere yönelik bir araştırma. İktisadi ve İdari Bilimler Dergisi, (1), 129-145.

Demirel, Y. \& Tohum, E. (2018). Örgütsel öğrenmenin örgütsel vatandaşlık davranışı üzerine etkisi. Íktisadi ve İdari Bilimler Fakültesi Sosyal Araştırmalar Dergisi, (2), 277-295.

Egan, T. M. Yang, B. \& Barlett, K. R. (2004). The effect of organizational learning culture and job satisfaction on motivation to transfer learning and turnover intention. Human Resource Development Quarterly, (3), 279-301.

Ergin, B. (2014). Türkiye'de yükseköğretim sisteminde kalite ve etkililik açısından kendi kendine liderlik yaklaşımının ögretim üyesi yetkinlikleri ve örgütsel ögrenme kapasitesi üzerine etkisi. Yayınlanmamış doktora tezi, Marmara Üniversitesi, İstanbul.

George, D. \& Mallery, P. (2010). SPSS for windows step by step: a simple study guide and reference (10. Baskı). Gen, Boston, MA: Pearson Education, İnc.

Gürbüz, S. (2006). Örgütsel vatandaşlık davranışı ile duygusal bağglılık arasındaki ilişkilerin belirlenmesine yönelik bir araştırma. AIBBÜ IIBFESA Dergisi, (1), 48-75.

Hackman, J. R. \& Oldham, G. R. (1975). Development of the job diagnostic survey. Journal of Applied Psychology, (2), 159-170.

Horuz, İ. (2018). 360 derece performans değerlendirme sisteminin örgütsel ögrrenme kapasitesi üzerine etkisine dair bir araştırma. Yayınlanmamış yüksek lisans tezi, Düzce Üniversitesi, Düzce.

İşcan, Ö. F. \& Sayın, U. (2010). Örgütsel adalet, iş tatmini ve örgütsel güven arasındaki ilişki. İktisadi ve İdari Bilimler Dergisi, (4), 195-216.

Joo, Y. J. \& Soonkwan, H. (2008). Organizational citizenship behavior and performance at the maquiladora. International Journal of Quality \& Reliability Management, (25), 793-808.

Kalaycı, Ş. (2010). SPSS Uygulamalı Çok değişkenli istatistik teknikler (5. baskı). Asil Yayın Dağıtım: Ankara.

Kara, A. (2019). İ̧̧ müşteri ilişkileri yönetiminin iç girişimcilik üzerindeki etkisi. Yayınlanmamış yüksek lisans tezi, Kastamonu Üniversitesi, Kastamonu.

Kayan, M. (2011). Yaşam kalitesi ve örgütsel vatandaşlık. Yayınlanmamış yüksek lisans tezi, Afyon Kocatepe Üniversitesi, Afyonkarahisar. 
Kaymakçı, K. (2013). Örgütsel vatandaşlık davranışı ve iş tatmini arasındaki ilişki: sağlık sektöründe bir araştırma. Yayınlanmamış yüksek lisans tezi, Pamukkale Üniversitesi, Denizli.

Lambert, E. G. (2010). The relationship of organizational citizenship behavior with job satisfaction, turnover intent, life satisfaction, and burnout among correctional staff. Criminal Justice Studies, (4), 361-380.

Lepine, J. A. Erez, A. \& Johnson, D. E. (2002). The nature and dimensionality of organizational citizenship behavior: a meta-analysis. Journal of Applied Psychology, (1), 5254 .

Lo, M. \& Ramayah, T. (2009). Dimensionality of organizational citizenship behavior in a multicultural society: the case of malaysia. International Business Research, (1), 48-55.

Mackenzie, S. B. Podsakoff, P. M. \& Fetter, R. (1993). The impact of organizational citizenship behavior on evalutions of salesperson performance. Journal of Marketing, (1), 7080 .

Mert, İ. S. (2010). İş tatmini alt boyutlarının örgütsel vatandaşlık davranışı üzerindeki etkisi: yöneticiler üzerine bir araştırma. EA Dergisi, (30), 117-143.

Miao, R. T. (2011). Perceived organizational support, job satisfaction, task performance and organizational citizenship behavior in china. University of Science and Technology Liaoning, (2), 105.

Najafi, S. Noruzy, A. Azar, H. K. Shirkouhi, S. N. \& Dalvand, M. R. (2011). Investigating the relationship between organizational justice, psychological empowerment, job satisfaction, organizational commietment and organizational citizenship behavior: an empirical model. African Journal of BusinessManagement, (13), 5241-5248.

Nevis, E. Dibella, A. J. \& Gould, J. M. (1995). Understanding organization learning systems. Sloan Management Review, (2), 73-85.

Organ, D. W. (1988). Organizational Citizenship Behavior: the Good Soldier Syndrome, Lexington Books/DC Heath and Com.

Öncül, M. S. (1999). Örgütsel öğrenme. MPMV Dergisi, (2), 7-24.

Özer, P. (2013). Özel hastanelerin örgütsel ögrrenme düzeyleri ile sağlık profesyonellerinin iş tatminleri ve iş yaşam kaliteleri arasındaki ilişki. Yayınlanmamış yüksek lisans tezi, Beykent Üniversitesi, İstanbul.

Podsakoff, P. M. Mackenzie, S. B. Paine, J. B. \& Bachrach, D. (2000). Organizational citizenship behaviors: a critical review of the theoretical and empirical literature and suggestions for future research. Journal of Management, (26), 513-563.

Rose, R. C. Kumar, N. \& Pak, O. G. (2009). The effect of organizational learning on organizational commitment, job satisfaction and work performance. The Journal of Applied Business Research, (6).

Schnake, M. Dumler, M. \& Cochran, D. S. (1993). The relationship between traditional leadership, super leadership and organizational citizenship behavior. Group \& Organizational Management, (3), 352-365. 
Scott, L. B. \& Christopher, C. A. (2004). Emotional intelligence and participation in decisionmaking: strategies for promoting organizational learning and change. Strategic Change, (2), 95-105.

Sezgin, F. (2005). Örgütsel vatandaşlık davranışları: kavramsal bir çözümleme ve okul açısından bazı çıkarımlar. GÜ GEF Dergisi, (1), 317-339.

Taşc1, D. \& Koç, U. (2007). Örgütsel vatandaşlık davranışı, örgütsel öğrenme değerleri ilişkisi: akademisyenler üzerinde görgül bir araştırma. Sosyal Bilimler Dergisi, (2), 373-382.

Tekin, E. (2019). Paternalist liderliğin iş tatmini ve çalışan performansına etkisi üzerine bir araştırma. KÜ IIBF ÜSSE Dergisi, (1), 178-204.

Toplu, D. B. (1998). Kamu kurum arşivlerinde çalışan personelin iş tatmini. Yayınlanmamış yüksek lisans tezi, Hacettepe Üniversitesi, Ankara.

Tsai, Y. \& Wu, S. W. (2010). The relationships between organizational citizenship behavior, job satisfaction and turnover intention. Journal of Clinical Nursing, (19), 23-24.

Vroom, V. H. (1967). Work and Motivation. New York: 3rd Printing.

Yeşilyurt, H. \& Koçak, N. (2014). İş doyumu ve örgütsel vatandaşlık davranışı arasındaki ilişkinin otel işletmeleri açısından incelenmesi. Dokuz Eylül Üniversitesi Sosyal Bilimler Enstitüsü Dergisi, (2), 303-324. 